\title{
Bernard Demont, Représentations spatiales et narration dans les contes et nouvelles de Guy de Maupassant
}

\section{Ida Merello}

\section{(2) OpenEdition}

\section{Journals}

\section{Edizione digitale}

URL: http://journals.openedition.org/studifrancesi/33533

DOI: $10.4000 /$ studifrancesi.33533

ISSN: 2421-5856

\section{Editore}

Rosenberg \& Sellier

\section{Edizione cartacea}

Data di pubblicazione: 1 décembre 2005

Paginazione: 670

ISSN: 0039-2944

\section{Notizia bibliografica digitale}

Ida Merello, «Bernard Demont, Représentations spatiales et narration dans les contes et nouvelles de Guy de Maupassant», Studi Francesi [Online], 147 (XLX | III) | 2005, online dal 30 novembre 2015, consultato il 22 avril 2021. URL: http://journals.openedition.org/studifrancesi/33533 ; DOI: https://doi.org/ 10.4000/studifrancesi.33533

Questo documento è stato generato automaticamente il 22 avril 2021.

\section{cc) $($ ) $\ominus$}

Studi Francesi è distribuita con Licenza Creative Commons Attribuzione - Non commerciale - Non opere derivate 4.0 Internazionale. 


\title{
Bernard Demont, Représentations spatiales et narration dans les contes et nouvelles de Guy de Maupassant
}

\author{
Ida Merello
}

\section{NOTIZIA}

BERNARD DEMONT, Représentations spatiales et narration dans les contes et nouvelles de Guy de Maupassant, Paris, Champion 2005, pp. 538.

1 L'A. prende in considerazione i racconti pubblicati tra il 1882 e il 1890, ma soprattutto prima del 1887, ossia quando è forte l'adesione al naturalismo e quindi la rappresentazione dello spazio come determinante sociale. Il presupposto è pertanto che l'ambientazione geografica svolga un ruolo di primo piano, al servizio di una struttura narrativa, rasentando il tematico e sempre in correlazione con un'attenzione psico-sociologica. L'A. arriva così a parlare di una retorica dello spazio geografico come interferenza che produce nel lettore una maggiore adesione alla finzione e procede a una stretta analisi narratologica suddividendo prima gli spazi e poi tentando di definirne il ruolo. Il confronto tra gli incipit permette di evidenziare come la disposizione spaziale dei personaggi sia già in grado di suggerire loro connotazioni positive o negative e alluda alla loro interrelazione, oppure come il rapporto con lo spazio costituisca una prefigurazione dell'atteggiamento caratteriale o, da ultimo, come l'uso di immagini metaforiche legate allo spazio svolga un ruolo profetico nei confronti delle vicende dei personaggi. L'A. individua inoltre riprese frequenti di medesimi schemi spaziali, strutture chiuse in rapporto con le metafore ossessive di Maupassant. 